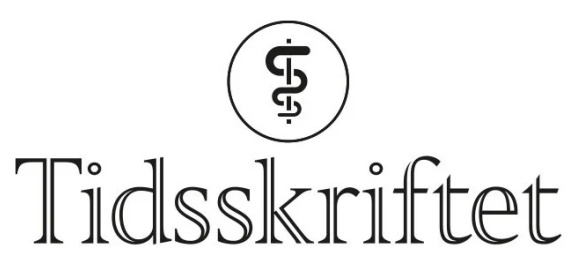

DEN NORSKE LEGEFORENING

\title{
Kristin Holstad
}

\author{
MINNEORD
}

SIGRID ØDEGÅRD

KJETIL BERGSMARK

GURO LøVIK GOLL

TILL UHLIG

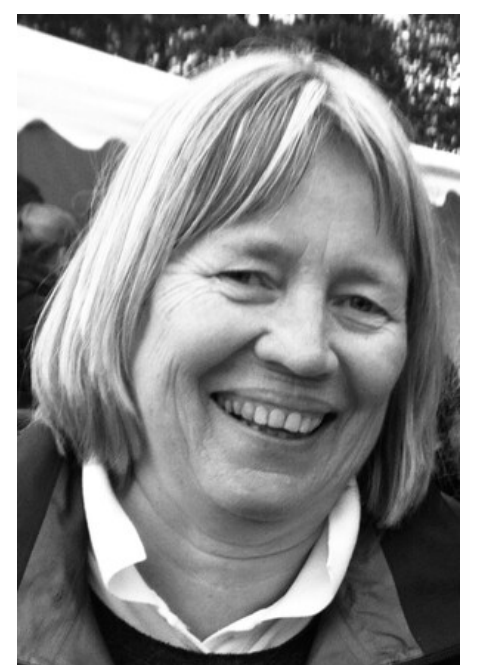

Vår gode venn og kollega Kristin Holstad født 2.2.1958 døde fredelig lørdag 24. april etter lengre tids sykdom.

Kristin tok sin spesialisering i generell indremedisin og revmatologi ved Universitetssykehuset i Linkjöping, og hadde fra 1997 virke som revmatolog ved Diakonhjemmet Sykehus. Hun var en avholdt seksjonsoverlege på revmatologisk sengepost i mange år.

Kristin møtte alle pasienter med en genuin interesse, omsorg og bred faglig kompetanse. Revmatologiske pasienter på sengepost har ofte kompleks sykdom, og med sin personlige robusthet hadde Kristin evne og styrke til å følge pasienter i langvarige og vonde sykdomsperioder. Hun forsto mer enn mange betydningen av å spille på avdelingens tverrfaglige ressurser. Dette var legekunst på sitt beste. 
Kanskje er det Kristins raushet vi vil savne mest. Hun tok lett på andres feil og mangler, og så stort på ting. Hun var fullstendig ujålete, vennlig og snill.

Vi er takknemlige for alle de gode og morsomme stundene i sosiale sammenhenger hvor Kristin fikk vise sine kreative evner. Kristin var en historieforteller, en ordkunstner og en eminent formidler av godlynt spøk. Tautogrammer og limericks blir stående som Kristins sosiale varemerke på avdelingen.

Til tross for sykdom og krevende behandling de siste fire årene, var Kristin i gode perioder i arbeid. Det var viktig for oss, og viktig for Kristin. Vi er glade for at Kristin fikk en fin sommer på hytta i Risør i 2020 sammen med sine nærmeste, sitt store vennenettverk og båten «Bølgen og meg».

Vi sitter tilbake med gode minner om varme, raushet, humor og glede. I tautogrammet Kristin skrev til avdelingen i 2018 står det: «Revma-avdelingen rekrutterer revmatologisk råmateriale rasende raskt». Vi klarer ikke å rekruttere en ny Kristin.

Vi lyser fred over Kristins gode minne.

På vegne av kolleger ved Diakonhjemmet Sykehus

Publisert: 16. august 2021. Tidsskr Nor Legeforen. DOI: 10.4045/tidsskr.21.0475

(C) Tidsskrift for Den norske legeforening 2023. Lastet ned fra tidsskriftet.no 26. april 2023. 